\title{
A next-generation chemistry database cartridge
}

\author{
Wolf D Ihlenfeldt \\ From 8th German Conference on Chemoinformatics: 26 CIC-Workshop \\ Goslar, Germany. 11-13 November 2012
}

\begin{abstract}
Storing chemical structures and reactions in relational databases with the aid of database extension modules usually called cartridges is an industry standard. Typically such cartridges provide a fixed set of functions to facilitate structure queries (full-structure, substructure, superstructure, similarity), chemistry data file import and export, sometimes structure manipulations or standardizations, and occasionally a defined set of property computations. We extend this model by transplanting a complete scriptable chemical information processing toolkit into a database extension. With the aid of this tool a new realm of custom chemistry data operations and queries can be accessed directly in the database, and by means of SQL functions that can be used in any SQL statement. We discuss the design of the software and prototypical solutions this it can deliver.
\end{abstract}

Published: 22 March 2013

Publish with ChemistryCentral and every scientist can read your work free of charge

"Open access provides opportunities to our colleagues in other parts of the globe, by allowing anyone to view the content free of charge."

W. Jeffery Hurst, The Hershey Company.

- available free of charge to the entire scientific community

- peer reviewed and published immediately upon acceptance

- cited in PubMed and archived on PubMed Central

- yours - you keep the copyright

Submit your manuscript here:

http://www.chemistrycentral.com/manuscript/

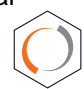

Chemistry Central

(c) 2013 Ihlenfeldt; licensee BioMed Central Ltd. This is an Open Access article distributed under the terms of the Creative Commons Chemistry Central Attribution License (http://creativecommons.org/licenses/by/2.0), which permits unrestricted use, distribution, and reproduction in any medium, provided the original work is properly cited. 